\title{
DYNAMIC INVENTORY MODELS: AN ILLUSTRATIVE CASE STUDY
}

\author{
K. Adendorff ${ }^{1} \&$ P.S. Kruger ${ }^{2 *}$ \\ ${ }^{1,2}$ Department of Industrial and Systems Engineering \\ University of Pretoria, South Africa \\ 2paul.kruger@up.ac.za
}

\begin{abstract}
The study revisits the subject matter of inventory control, a continual part of the activities of wide-ranging organisations internationally. The mathematical model is presented of a particular situation that deals with the regular acquisition of a material required for a production process in a volatile environment of varying demand and fluctuating price. The usual process dynamics are demonstrated against a background of diverse choices of probability density function. The model makes use of Normal and Weibull distributions.
\end{abstract}

\section{OPSOMMING}

Die studie herbesoek die bakermat van voorraadbeheer om hernude klem te lê op die ontwikkeling van gepaste wiskundige modelle vir uiteenlopende voorraadsituasies wat tans internasionaal met welslae gebruik kan word. 'n Rudimentêre model word voorgehou wat desnieteenstaande eenvoud dog onmisbare gereedskap soos Dinamiese Programmering en keuse van kansdigtheidsfunksie voorhou vir stogastiese behandeling van die onbestendige gedrag met verloop van tyd van voorraadprys- en aanvraag. Die model gebruik Normaal- en Weibullverdelings.

\footnotetext{
* Corresponding author
} 


\section{$1 \quad$ INTRODUCTION}

"Almost any realistic decision problem has two fundamental characteristics: it is
sequential and it is uncertain. An excellent example of a sequential decision problem
under uncertainty is the holding of inventories." Arrow [1]

The present-day field of inventory control has reached such a stage that practising industrial and systems engineers may easily be overwhelmed by the extensive population of vagaries that may be encountered in attempting to select, design, and successfully operate a reliable inventory control system. The menu of opportunities is fraught, inter alia, with advanced concepts such as Dynamic Programming [2] and Stochastic Systems [3] that may be employed to good effect in practice.

The numeric case study presented here deals with an organisation in the agricultural sector that purchases a raw material to be used as an ingredient of a weed-killing preparation. The raw material price fluctuates with the passage of time, as does demand for the raw material.

To illustrate the creation of an inventory model suited to the problem, a two-period policy is initially considered without loss of applicability for $n$-period policies [3].

\section{THE MODEL}

The stochastic and dynamic nature of a two-period model, as proposed by [3], relates to achieving assurance of an outcome by using the applicable observations and constraints. To this end, the formulation of the model for the expected cost of the $n$-period optimal policy as provided by [3] is shown in equation (1):

$f_{n}(s, P)=\min _{S \geq s}\left\{(S-s) P+I(S)+\int_{0}^{\infty} \int_{0}^{S} f_{n-1}(S-r, p) \phi(r) \varphi(p) \mathrm{d} r \mathrm{~d} p\right\}$

where

$\mathrm{n}$ is the period,

$s$ is the quantity of inventory on hand at the beginning of the period,

$\mathrm{P}$ is the market price of the commodity,

$\mathrm{S}$ is the stock level at the beginning of the first period,

$\mathrm{I}(\mathrm{S})$ is the holding and shortage cost in period one,

$\phi(r)$ is the distribution of the demand (units / period),

$\varphi(p)$ is the distribution of the price (Rand / unit), and

$r$ and $p$ are integration variables.

A brief description of the particular modelling environment includes the following features:

- $\quad$ The inventory level is unconstrained.

- Inventory is replenished instantaneously if required.

- Surplus inventory is not sold.

- Inventory holding and shortage costs are considered.

- The distributions of demand and price are independent.

- The final model is created in two sequential stages by proceeding via a single period policy to an eventual two-period policy.

\subsection{The Normal demand distribution}

The Normal distribution is initially used to create the mathematical functions that are required for the single period model stage shown in Table 1 . The values used are as follows: 
Mean: 36 units/ period,

Standard deviation: 10.5 units per period,

Inventory holding cost $=\mathrm{C}_{1}=10.00$ Rand per unit period, and

Inventory shortage cost $=c_{2}=130.00$ Rand per unit.

The obtained values of the terms in equation (1) are shown in Table 1. These values are provided primarily for purposes of illustration. The integral of the Normal distribution is obtained by fitting a logistic function to the cumulative function of the Normal distribution using non-linear regression. The same result may be obtained by using the built-in relevant function provided by, for example, Microsoft Excel. The values for $x$ have been chosen to reflect the mean plus or minus three standard deviations of the demand distribution.

Table 1: Function values required for the single period model

\begin{tabular}{|c|c|c|c|c|c|}
\hline$x$ & $\int_{0}^{\infty}\left\{\frac{\phi(x)}{x}\right\} \mathrm{d} x$ & $\phi(x)$ & $\frac{\phi(x)}{x}$ & $\int_{0}^{\infty} \phi(x) \mathrm{d} x$ & $\int_{0}^{s} \phi(x) \mathrm{d} x$ \\
\hline 4.5 & $3.0677 \mathrm{E}-02$ & 0.0004 & $9.380 \mathrm{E}-05$ & 0.9987 & 0.0013 \\
\hline 15 & $2.8721 \mathrm{E}-02$ & 0.0051 & $3.428 \mathrm{E}-04$ & 0.9772 & 0.0228 \\
\hline 25.5 & $2.2000 \mathrm{E}-02$ & 0.0230 & $9.037 \mathrm{E}-04$ & 0.8413 & 0.1587 \\
\hline 30.75 & $1.6277 \mathrm{E}-02$ & 0.0335 & $1.090 \mathrm{E}-03$ & 0.6915 & 0.3085 \\
\hline 36 & $1.0372 \mathrm{E}-02$ & 0.0379 & $1.055 \mathrm{E}-03$ & 0.5000 & 0.5000 \\
\hline 41.25 & $5.7812 \mathrm{E}-03$ & 0.0335 & $8.128 \mathrm{E}-04$ & 0.3085 & 0.6915 \\
\hline 46.5 & $2.9364 \mathrm{E}-03$ & 0.0230 & $4.956 \mathrm{E}-04$ & 0.1587 & 0.8413 \\
\hline 57 & $6.6216 \mathrm{E}-04$ & 0.0051 & $9.021 \mathrm{E}-05$ & 0.0228 & 0.9772 \\
\hline 67.5 & $1.4056 \mathrm{E}-04$ & 0.0004 & $6.253 \mathrm{E}-06$ & 0.0013 & 0.9987 \\
\hline
\end{tabular}

To determine the market price (Rand per unit) of the raw material at the beginning of the period, equation (2) is applied [3]:

$p_{1}(s)=c_{2} \int_{s}^{\infty} \varphi(x) \mathrm{d} x-c_{1} s \int_{s}^{\infty}\left\{\frac{\varphi(x)}{x}\right\} \mathrm{d} x-c_{1} \int_{0}^{s} \varphi(x) \mathrm{d} x$

\subsection{The Weibull price distribution}

The Weibull distribution [4] is selected to serve as a tool in establishing the purchasing policy described below. The reason for this choice is that it is versatile, and is often used in analysing industrial and systems engineering problems. 


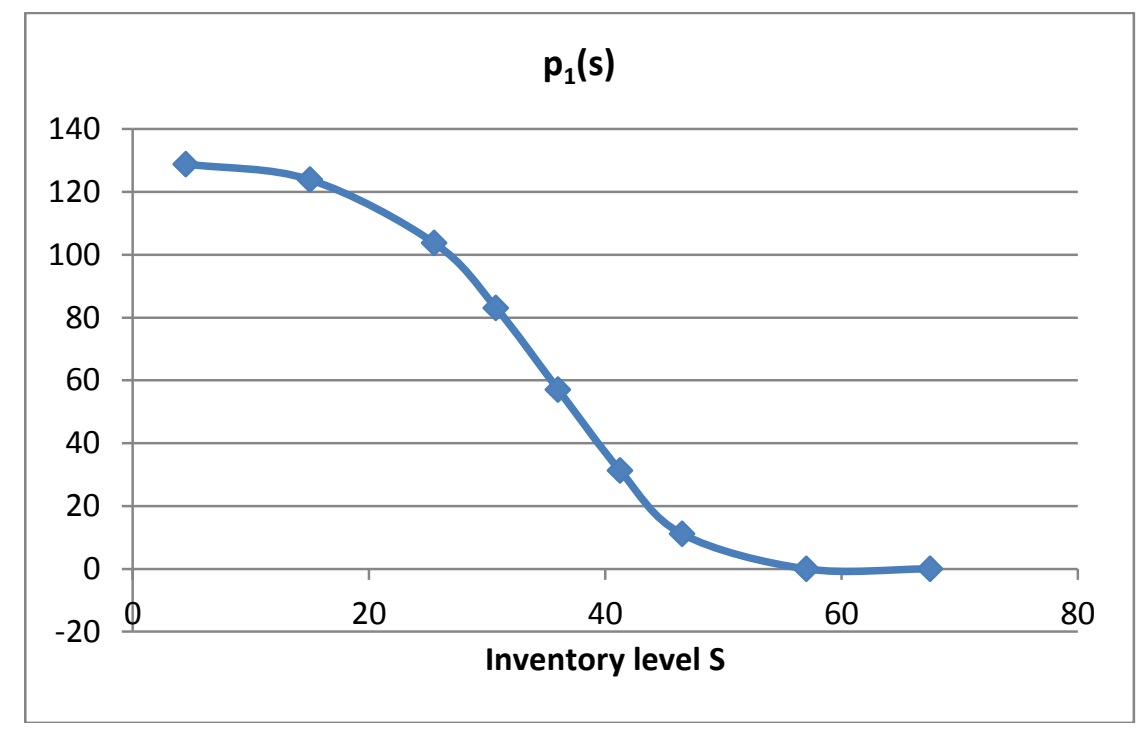

Figure 1: Price per unit of initial inventory level

Table 2: Single period unit price calculations

\begin{tabular}{|c|c|c|c|c|}
\hline$s$ & $c_{2} \int_{s}^{\infty} \varphi(x) \mathrm{d} x$ & $c_{1} s \int_{s}^{\infty}\left\{\frac{\varphi(x)}{x}\right\} \mathrm{d} x$ & $c_{1} \int_{0}^{s} \varphi(x) \mathrm{d} x$ & $p_{1}(s)$ \\
\hline 4.50 & 129.83 & -1.3805 & -0.01300 & 128.89 \\
\hline 15.00 & 127.04 & -4.3083 & -0.22800 & 123.89 \\
\hline 25.50 & 109.37 & -5.6102 & -1.58700 & 103.80 \\
\hline 30.75 & 89.90 & -5.0054 & -3.08500 & 83.12 \\
\hline 36.00 & 65.00 & -3.7340 & -5.00000 & 57.13 \\
\hline 41.25 & 40.11 & -2.3848 & -6.91500 & 31.29 \\
\hline 46.50 & 20.63 & -1.3654 & -8.41300 & 11.11 \\
\hline 57.00 & 2.96 & -0.3774 & -9.77200 & 0.00 \\
\hline 67.50 & 0.17 & -0.0949 & -9.98700 & 0.00 \\
\hline
\end{tabular}

To establish the correct two-period purchasing policy $p_{2}(s)$, the distribution given in Table 3 below is used to create functions to model the second period model stage, as shown in Table 4. The symbols and values are as follows:

Mean: 250 Rand/ unit

Shape parameter: $\quad c=3$ (chosen for the sake of convenience)

Scale parameter: $\quad b=($ Mean $) /[(c+1) / c)]=250 / 0.8930=280$

$\mathrm{p}_{\mathrm{n}}=$ future price per unit (Rand)

$\varphi(p)=$ probability density function of future price per unit.

The determination of $p_{2}(s)$ typically employs equation (3) over the range of s-values from 4.50 to $67.5[3]:$

$p_{2}(s)=p_{1}(s)+\int_{0}^{s}\left\{\int_{0}^{p_{1}(s-x)} p \varphi(p) \mathrm{d} p+\int_{p_{1}(s-x)}^{\infty} p_{1}(s-x) \varphi(p) \mathrm{d} p\right\} \varphi(x) \mathrm{d} x$ 
Table 3: Weibull price distribution

\begin{tabular}{|c|c|c|c|}
\hline$p$ & $\varphi(p)$ & $p \varphi(p)$ & $\int_{0}^{\infty} p \varphi(p) \mathrm{d} p$ \\
\hline 0 & 0.0000 & 0 & 0 \\
\hline 100 & 0.0013 & 0.1306 & 0.0446 \\
\hline 200 & 0.0038 & 0.7596 & 0.3055 \\
\hline 300 & 0.0036 & 1.0785 & 0.7078 \\
\hline 400 & 0.0012 & 0.4754 & 0.9459 \\
\hline 500 & 0.0001 & 0.0574 & 0.9966 \\
\hline 600 & 0.0000 & 0.0016 & 0.9999 \\
\hline 700 & 0.0000 & 0.0000 & 0.9999 \\
\hline 800 & 0.0000 & 0.0000 & 1.0000 \\
\hline
\end{tabular}

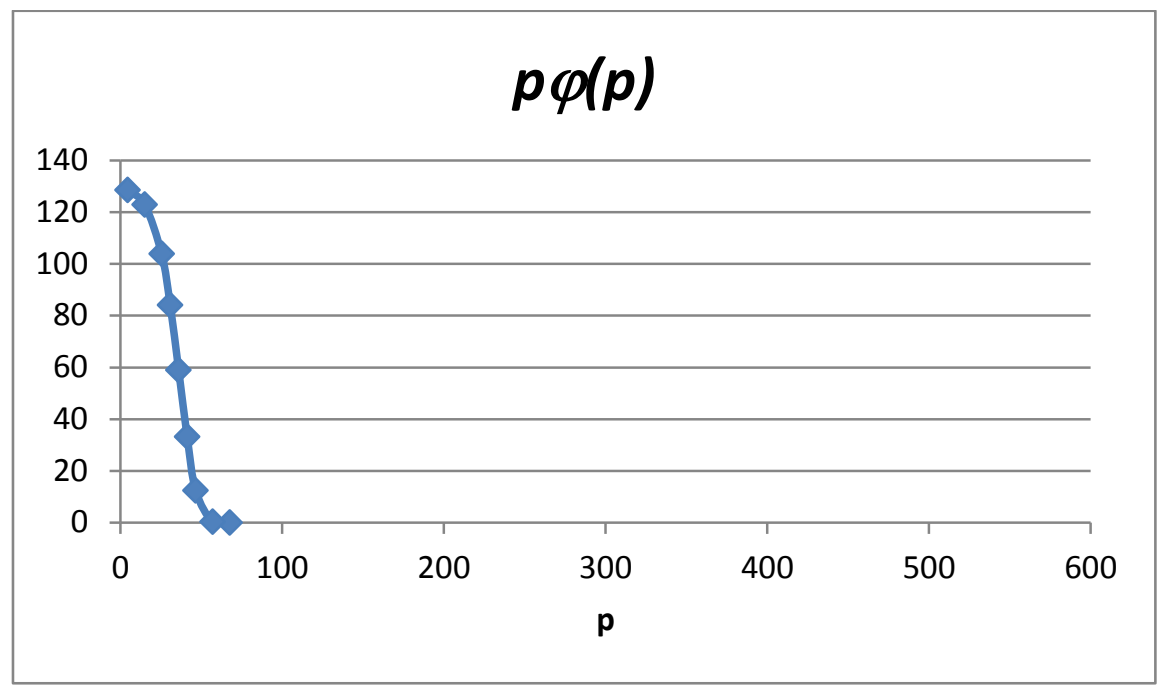

Figure 2: Weibull function 
Table 4: Function values for the second period stage for $S=67.5$

\begin{tabular}{|c|c|c|c|c|c|c|c|c|}
\hline$s$ & $x$ & $s-x$ & $\varphi(x)$ & $p_{1}(s-x)$ & $\int_{0}^{p_{1}(s-x)} p_{1}(s-x) \mathrm{d} p$ & $\varphi(x) \int_{0}^{p_{1}(s-x)} p_{1}(s-x) \mathrm{d} p$ & $\int_{p_{1}(s-x)}^{\infty} p_{1}(s-x) \varphi(p) \mathrm{d} p$ & $\varphi(x) \int_{p_{1}(s-x)}^{\infty} p_{1}(s-x) \varphi(p) \mathrm{d} p$ \\
\hline 67.5 & 4.50 & 63.00 & 0.00042 & 14.66 & $1.440 \mathrm{E}-04$ & $6.060 \mathrm{E}-08$ & $9.999 \mathrm{E}-01$ & $4.200 \mathrm{E}-04$ \\
\hline 67.5 & 15.00 & 52.50 & 0.00514 & 17.54 & $2.66 \mathrm{E}-04$ & $1.000 \mathrm{E}-10$ & $1.3672 \mathrm{E}-07$ & $5.140 \mathrm{E}-03$ \\
\hline 67.5 & 25.50 & 42.00 & 0.02304 & 20.42 & $3.880 \mathrm{E}-04$ & $8.943 \mathrm{E}-06$ & $9.996 \mathrm{E}-01$ & $2.304 \mathrm{E}-02$ \\
\hline 67.5 & 30.75 & 36.75 & 0.03353 & 37.98 & $2.494 \mathrm{E}-04$ & $8.361 \mathrm{E}-05$ & $9.975 \mathrm{E}-01$ & $3.345 \mathrm{E}-02$ \\
\hline 67.5 & 36.00 & 31.50 & 0.03799 & 58.17 & $8.927 \mathrm{E}-03$ & $3.392 \mathrm{E}-04$ & $9.991 \mathrm{E}-01$ & $3.766 \mathrm{E}-02$ \\
\hline 67.5 & 41.25 & 26.25 & 0.03353 & 79.07 & $2.227 \mathrm{E}-03$ & $7.468 \mathrm{E}-04$ & $9.777 \mathrm{E}-01$ & $3.278 \mathrm{E}-02$ \\
\hline 67.5 & 46.50 & 21.00 & 0.02304 & 98.77 & $4.296 \mathrm{E}-03$ & $9.901 \mathrm{E}-04$ & $9.570 \mathrm{E}-01$ & $2.109 \mathrm{E}-01$ \\
\hline 67.5 & 57.00 & 10.50 & 0.00514 & 126.97 & $8.906 \mathrm{E}-02$ & $4.579 \mathrm{E}-04$ & $3.05 \mathrm{E}-02$ \\
\hline 67.5 & 67.50 & 0.00 & 0.00042 & 127.47 & $9.006 \mathrm{E}-03$ & $3.802 \mathrm{E}-05$ & $9.099 \mathrm{E}-01$ & $4.680 \mathrm{E}-03$ \\
\hline
\end{tabular}


Table 5: Two-period unit price calculations

\begin{tabular}{|c|c|c|c|c|}
\hline$s$ & $p_{1}(s)$ & $\int_{0}^{s} \varphi(x) \int_{0}^{p_{1}(s-x)} p \varphi(p) \mathrm{d} p \mathrm{~d} x$ & $\int_{0}^{s} \varphi(x) \int_{p_{1}(s-x)}^{\infty} p_{1}(s-x) \varphi(p) \mathrm{d} p \mathrm{~d} x$ & $p_{2}(s)$ \\
\hline 67.50 & 0.00 & 0.0000 & 0.0285 & 0.03 \\
\hline 57.00 & 0.00 & 0.0000 & 0.3471 & 0.35 \\
\hline 46.50 & 10.85 & 0.0006 & 1.5550 & 12.41 \\
\hline 41.25 & 30.87 & 0.0056 & 2.2576 & 33.13 \\
\hline 36.00 & 56.27 & 0.0229 & 2.5147 & 58.83 \\
\hline 30.75 & 81.80 & 0.0504 & 2.2129 & 84.06 \\
\hline 25.50 & 102.17 & 0.0668 & 1.4887 & 103.73 \\
\hline 15.00 & 122.50 & 0.0309 & 0.3162 & 122.85 \\
\hline 4.50 & 128.44 & 0.0256 & 0.0259 & 128.47 \\
\hline
\end{tabular}

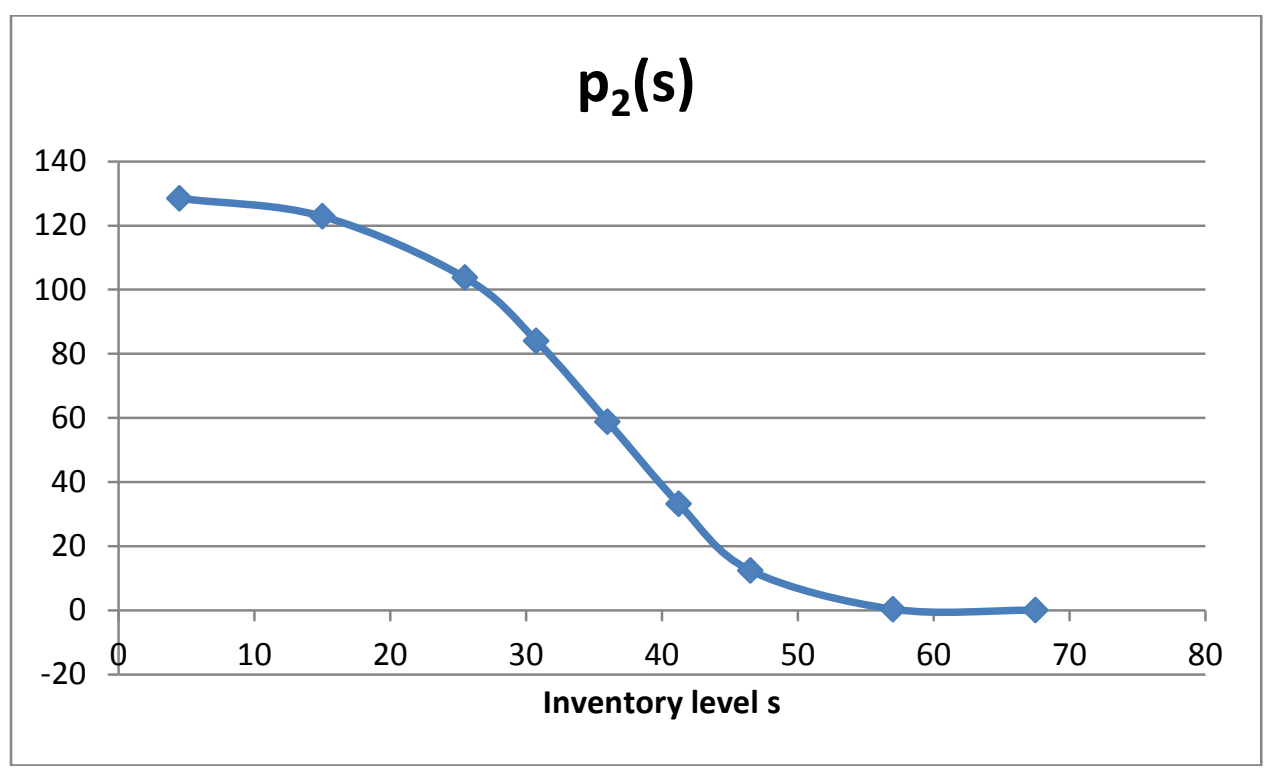

Figure 3: Price per unit of initial inventory level

The value of $p_{2}(s)$ as a function of $s$ is shown in Figure 3 . The curve depicts the essence of the model that is used to operate the inventory system optimally, as follows:

- $\quad$ The current unit price $p_{2}(s)$ of the raw material must be determined at the beginning of the period.

- $\quad$ The optimum inventory level may be read from the curve in Figure 3.

- Should the actual inventory level, $x$, be less than $s$, an order size of $(s-x)$ shall be purchased. Alternatively, if the actual inventory level is greater than $\mathrm{s}$, replenishment should not take place.

\section{CONCLUSION}

The elementary case study of this paper emphasises features of a quantitative nature for purposes of demonstration, and does not cater for subjectivity. Its tutorial-like flavour is meant to encourage practitioners and the uninitiated to explore the trail of information, which is presented here in truncated form. 
To have confidence in the optimisation dictated by equation (2), the operation of the system has been simulated and compared with non-optimal operation. The simulation exercise indicates a $9 \%$ saving in the cost of holding inventory.

\section{REFERENCES}

[1] Arrow, K.J. 1957. Statistics and economic policy. Econometrica 25, 523-531.

[2] Bellmann, R. 1957. Dynamic programming. Princeton University Press.

[3] Fabian, T., Fisher, J.L., Sasieni, M.W. \& Yardeni, A. 1958. Purchasing raw material on a fluctuating market. Cleveland, Ohio: Case Institute of Technology.

[4] Lai, C.D., Murthy, D. N. P. \& Xie, M. 2011. Weibull distributions. Wiley Interdisciplinary Reviews: Computational Statistics, 3(3), 282-287.

[5] Naddor, E. 1966, Inventory systems. J ohn Wiley \& Sons, Inc. 